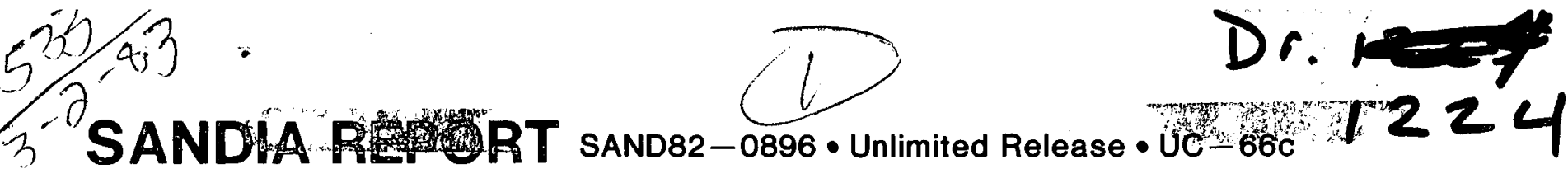

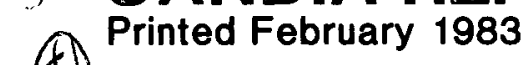

A Printed February 1983

$I-8 / 38$

\title{
Investigation of the Potential for Using \\ Electrochemical Technology to \\ Reduce Drill Bit Wear
}

\author{
SAND--82-0896 \\ DES3 007373
}

Thomas E. Hinkebein, David A. Glowka

Prepared by

Sandia National Laboratories

Albuquerque, New Mexico 87185 and Livermore, California 94550

for the United States Department of Energy

under Contract DE-AC04-76DP00789 


\section{DISCLAIMER}

This report was prepared as an account of work sponsored by an agency of the United States Government. Neither the United States Government nor any agency Thereof, nor any of their employees, makes any warranty, express or implied, or assumes any legal liability or responsibility for the accuracy, completeness, or usefulness of any information, apparatus, product, or process disclosed, or represents that its use would not infringe privately owned rights. Reference herein to any specific commercial product, process, or service by trade name, trademark, manufacturer, or otherwise does not necessarily constitute or imply its endorsement, recommendation, or favoring by the United States Government or any agency thereof. The views and opinions of authors expressed herein do not necessarily state or reflect those of the United States Government or any agency thereof. 


\section{DISCLAIMER}

Portions of this document may be illegible in electronic image products. Images are produced from the best available original document. 
Issued by Sandia National Laboratories, operated for the United States Department of Energy by Sandia Corporation.

NOTICE: This report was prepared as an account of work sponsored by an agency of the United States Government. Neither the United States Government nor any agency thereof, nor any of their employees, nor any of their contractors, subcontractors, or their employees, makes any warranty, express or implied, or assumes any legal liability or responsibility for the accuracy, completeness, or usefulness of any information, apparatus, product, or process disclosed, or represents that its use would not infringe privately owned rights. Reference herein to any specific commercial product, process, or service by trade name, trademark, manufacturer, or otherwise, does not necessarily constitute or imply its endorsement, recommendation, or favoring by the United States Government, any agency thereof or any of their contractors or subcontractors. The views and opinions expressed herein do not necessarily state or reflect those of the United States Government, any agency thereof or any of their contractors or subcontractors.

Printed in the United States of America Available from

National Technical Information Service

U.S. Department of Commerce

5285 Port Royal Road

Springfield, VA 22161

NTIS price codes

Printed copy: A03

Microfiche copy: A0 
SAND82-0896

Unlimited Release

Printed February 1982

Distribution

Category UC-66c

\title{
INVESTIGATION OF THE POTENTIAL.FOR USING ELECTROCHEMICAL TECHNOLOGY TO REDUCE DRILL BIT WEAR
}

Thomas E. Hinkebein

Enhanced Oil Recovery, Division 9755

David A. Glowka

Geothermal Technology Development, Division 9741

\begin{abstract}
Recent work has shown that an important drill bit wear mechanism in aqueous environments is electrochemical in nature. The synergistic effects of corrosion and abrasion are responsible for a large percentage of bit wear in laboratory studies. It has been shown that measured wear rates can be reduced by factors of two to five with the application of a voltage potential which opposes and exceeds the galvanic potential generated by the corrosion cells existing downhole. The present study investigates the potential for applying this technique in the downhole environment. The results demonstrate that a downhole generator sub powered by drilling fluid is a possible electrical power source. Graphite is chosen as the optimal nonsacrificial anode material for this application. Steel is also shown to be a possible anode material, but the anode would be sacrificial in this case, requiring periodic replacement. The electrical power required to achieve the desired effect for a 4-1/2 inch drill bit is determined to be on the order of one milliwatt. Additionally, up to 250 feet of 4 inch drill pipe could be protected from corrosion with power levels on the order of 150 milliwatts. These relatively low power levels suggest that dry cell batteries could alternatively be employed as the power source; however, the temperature limitations of commercially available batteries would have to be overcome for geotherma1 app1ications.

\section{DISCLAIMER}

This report was prepared as an account of work sponsored by an agency of the United States Government. Neither the United States Government nor any agency thereof, nor any of their employees, makes any warranty, express or implied, or assumes any legal liability or responsibility for the accuracy, completeness, or usefulness of any information, apparatus, product, or process disclosed, or represents that its use would not infringe privately owned rights. Reference herein to any specific commercial product, process, or service by trade name, trademark, manufacturer, or otherwise does not necessarily constitute or imply its endorsement, recommendation, or favoring by the United States Government or any agency thereof. The views and opinions of authors expressed herein do not necessarily state or reflect those of the United States Government or any agency thereof.

DiSTPIBUTION OF THS DOCIMANT IS UNLIMHED 
CONTENTS $\quad$ Page

Introduction $\ldots \ldots \ldots \ldots \ldots \ldots \ldots \ldots \ldots \ldots \ldots \ldots \ldots \ldots \ldots \ldots \ldots \ldots \ldots$

Implementation of Wear Reduction Principles

to Field operation ......................... 8

Laboratory Testing Procedures .................. 10

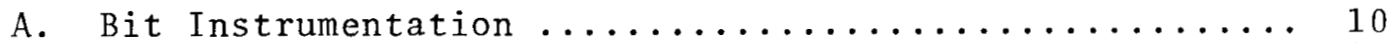

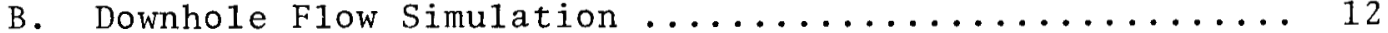

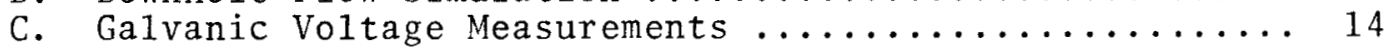

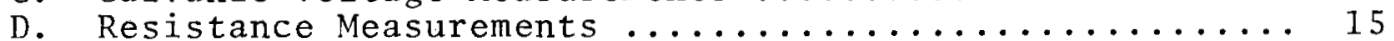

E. Voltage Drop Measurements ..................... 16

Presentation of Results ...................... 18

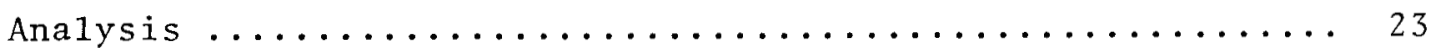

A. Description of Electrical Path ................ 23

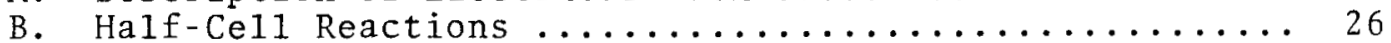

C. Power and Voltage Requirements .................. 30

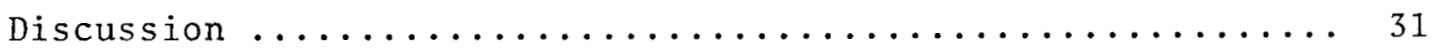

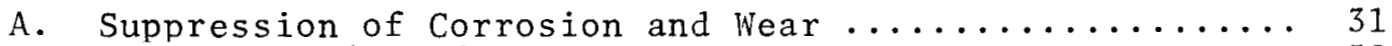

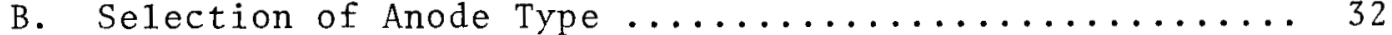

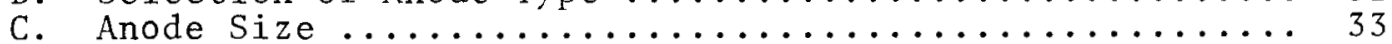

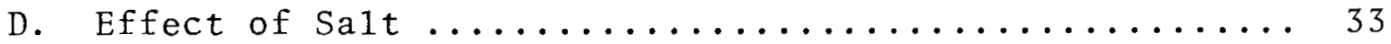

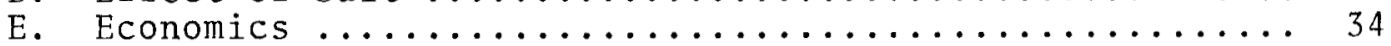

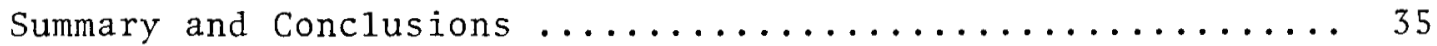

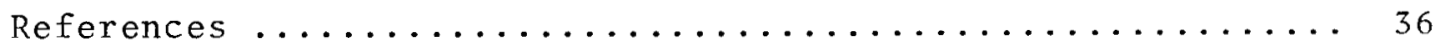


TABLES Page

1 - Galvanic Voltage Measurements ................... 19

2 - Resistance Measurements ................... 20

3 - Voltage Drop Measurements ................... 21

4 - Total Current and Power Measurements ............ 22

5 - Potential Well Cost Savings ................ 35

\section{FIGURES}

1 - Proposed Downhole Fluid-Powered Generator Sub ....... 9

2 - Instrumented 4-1/2" Three-Cone Roller Bit .......... 11

3 - Instrumented Bit Showing Anode Fixture ........... 12

4 - Bit Hydraulics Test Stand .................. 13

5 - Circuit for Measuring Effective Resistances ......... 16

6 - Circuit for Measuring Voltage Drops .............. 17

7 - Circuit for Measuring Tota 1 Current ............ 17

8 - Anodes Employed in Study .................. 23 


\section{INTRODUCTION}

The recent work by Hoenig, et a.$^{1}$ has shown that electrochemical wear mechanisms in the presence of water are very important. In his sma11-scale experiments Hoenig found that an electrical current accompanies the wear of a tungsten carbide drag bit drilling in various rocks such that there is a flow of electrons up the drill bit (the anode) and toward the rock (the cathode). This electron flow implies that metal, $M$, dissolution is taking place at the anode, and oxygen reduction is taking place at the cathodic rock surface according to the reactions,

$$
\begin{gathered}
M \rightarrow M^{+}+e^{-} \\
O_{2}+2 \mathrm{H}_{2} \mathrm{O}+4 \mathrm{e}^{-} \rightarrow 40 \mathrm{H}^{-}
\end{gathered}
$$

These reactions are identical to those occurring during corrosion, and this similarity led Hoenig to believe that the suppression of corrosion and, hence, wear may be accomplished by the application of a reverse voltage which causes the metal surface to become cathodic. To this end, Hoenig found that very small reverse currents reduced measured drill bit wear rates by factors of between two to five, depending on the rock type, penetration rate, and oxygen content of the drilling fluid.

As a consequence of Hoenig's finding, it may be speculated that actual drill bit wear in the field may be substantially reduced by electrically protecting the drill bit and employing a sacrificial anode to reduce corrosion. The actual results obtained in the field will probably reflect some differences in the relative importance of various wear mechanisms, but substantial improvement is to be expected. This improvement will likely come from the suppression of the synergistic effects of corrosion, erosion and abrasion. These have been reported in previous corrosion data. ${ }^{2}$ It is well known that corrosive metal loss on the external surface of drill pipe is an order of magnitude larger than that 
which occurs on the inside of the drill pipe since rock chips act on the outside of the pipe to abrade the metal surface. However, if the corrosive action of the fluid is reduced by an order of magnitude through the removal of dissolved oxygen, then the abrasion-corrosion mechanism is also strongly reduced such that an order of magnitude reduction in metal loss by the combined mechanism is also observed. ${ }^{7}$ Hence, we may expect that the suppression of the corrosion mechanism may strongly impact the other wear mechanisms for a drill bit.

\section{IMPLEMENTATION OF WEAR REDUCTION PRINCIPLES TO FIELD OPERATION}

While laboratory experiments have demonstrated the feasibility of reducing wear through the application of an electrical potential, the method of implementing this phenomenon in the field must be considered in some detail. The application of surface generator to provide a downhole potential through the use of slip rings and joint connectors would be cumbersome, dangerous to personnel at the surface, and may be ineffective due to voltage attenuation. In addition, a downhole anode should be provided to assure that localized corrosion does not result. The downhole generator sub shown in Figure 1 is considered to be the most reasonable approach to providing a downhole source of electrical power. Downhole generator subs could be inserted above the bit and at specified intervals along the drill string to reduce abrasive-corrosive wear of all downhole equipment. A small electrical current would be generated in the conductor windings through the rotation of a permanent magnet mounted to a single-stage turbine blade powered by the drilling fluid. The resulting alternating current could be rectified to produce the direct current required for this application. An anode, insulated from the drill string, would be provided to assure an ionic pathway that would protect the drill bit. A voltage potential could thus be applied between the anode (positive) and the sub body (negative), which would be 


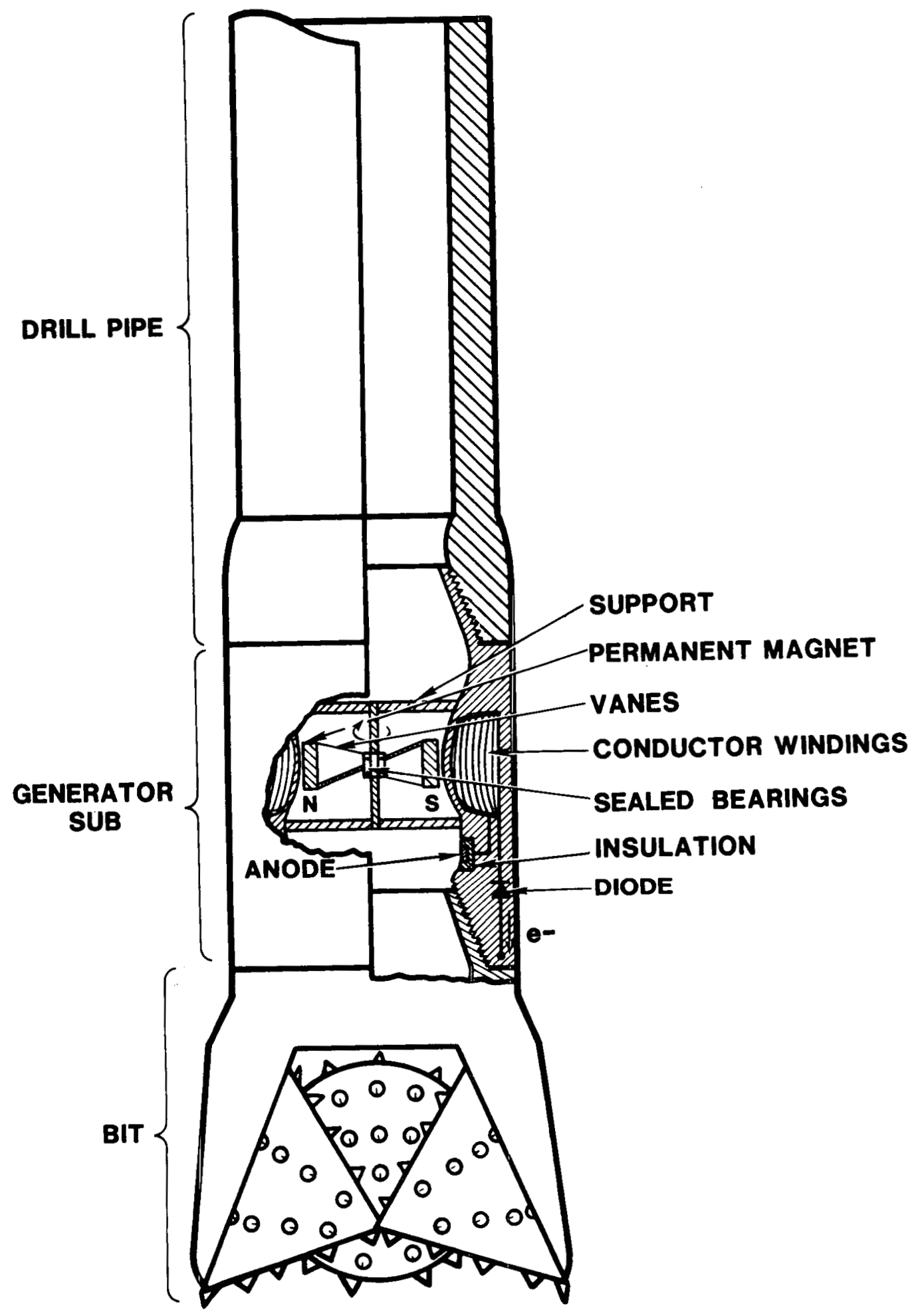

Figure 1. Proposed Downhole

F1uid-Powered

Generator Sub 
in direct electrical contact with the bit and drill string, causing them to become the cathode. A voltage limiting device, such as a zener diode, could be incorporated to assure that excessively large voltages do not occur, since this would lead to the production of hydrogen at the cathode, as shown in a later section. Evolved hydrogen could cause embrittlement problems for the drill string which are highly undesirable.

The tests conducted in this study suggest that the electrical power levels required to protect downhole equipment from corrosion are extremely sma11. This suggests the possibility of employing dry cell batteries as an alternative downhole power source. A survey of dry cel1 shows that there are commercial designs capable of supplying sufficient power with adequate lifetimes at low temperatures. The high temperature environment encountered when drilling geothermal formations, however, may preclude the use of dry cell batteries in this application unless batteries with high temperature capabilities are developed.

\section{LABORATORY TESTING PROCEDURES}

Laboratory tests have been performed to determine the feasibility as well as the operating characteristics required of a downhole power source. The purpose of these tests was to determine the required power levels for the generator as well as to verify that the application of a constant voltage across the bit and anode would result in complete cathodic protection for the bit. Since electrochemical reactions occur at both the cathode (bit) and the anode with their resultant ionic migration in the fluid, electrical current requirements are expected to be dictated by flow paths, solution concentration, fluid flow rates, and voltage levels. In addition, several anodic materials were tested to examine the less wel1 known effects of corrosion and scale formation.

\section{A. Bit Instrumentation}

In order to assess the magnitude of voltage attenuation across a 
bit and to measure the total current requirements anticipated for the downhole generator sub, a 4-1/2 inch, three-cone roller bit was instrumented as shown in Figure 2. This instrumentation consists of wires attached to several locations on the bit.

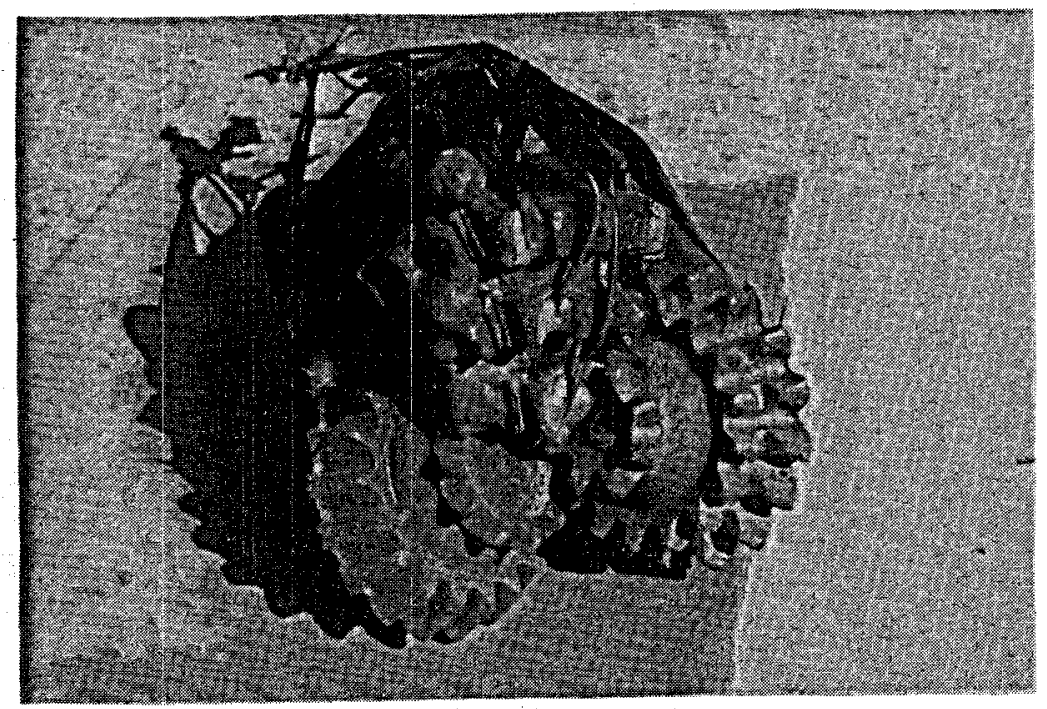

Figure 2. Instrumented 4-1/2" Three-Cone Ro1ler Bit

Two varieties of leads are attached, contacting and noncontacting. Three contacting leads ( $\mathrm{C} 1, \mathrm{C} 2$, and $\mathrm{C} 3$ ) are brazed directly to separate teeth on one of the cones, thereby providing direct electrical contact with the bit. The fourth contacting lead (B) is brazed directly to the bit body. Each contacting lead is insulated along its entire length.

There are four noncontacting leads, three on a cone (N1, N2, and N3) and one on the bit body (N4). Each noncontacting wire is attached with insulating epoxy such that no electrical contact is made with the bit. The tip of each of these leads is bare, and the remaining lengths are insulated with shrink tubing. A11 leads, both contacting and noncontacting, are made of $0.13 \mathrm{~cm}$ steel wire. The purpose in using steel was to minimize galvanic voltages between the wires and the steel bit. In addition to the lead wires described above, the bit was fitted with a threaded fixture consisting of two nuts brazed together, into 
which a $0.64 \mathrm{~cm}$ diameter anode can be screwed. The fixture is insulated and mounted inside the throat of the bit. (Figure 3.) An insulated steel wire (A) is attached to the fixture for the purpose of applying voltages to the anode. The fixture is configured so that anodes can be easily changed, thereby allowing different anode materials to be tested.

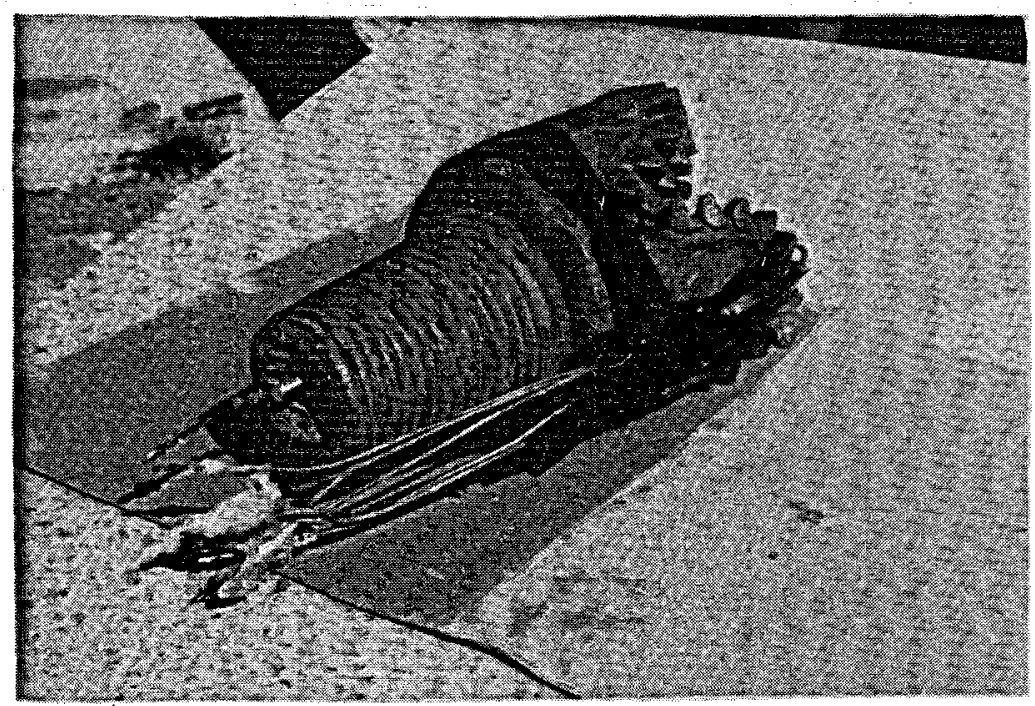

Figure 3. Instrumented Bit Showing Anode Fixture

The lead wires described above allow several electrical characteristics of the bit to be measured. Voltages may be applied between various leads, allowing currents and electrical resistances to be measured between the corresponding points on the bit. This data is used to determine the voltage attenuation across the bit and the total current and power requirements for the downhole generator sub. The following subsections describe the objectives and procedures for each type of measurement taken in this study.

\section{B. Downhole Flow Simulation}

Current flow through an electrolytic solution is accomplished through the flow of ions rather than electrons, as with current flow through metals. One factor influencing the magnitude of the current is the mobility of these ions, which in turn is influenced by the convection of the electrolytic solution. It is therefore important in studying current 
flow through electrolytes to simulate the flow field for which data is desired.

To simulate the downhole flow field in this study, the instrumented bit was placed in Sandia's bit hydraulics test stand, shown diagrammatically in Figure 4. This facility, described in detail in reference 3 , permits a bit to be threaded onto a drill pipe and placed in a transparent, simulated borehole. The bit may be rotated while fluid is pumped through the system, thereby simulating the downhole flow field. The test stand is fitted with a slip ring assembly to permit signals to be transferred to and from an instrumented bit.

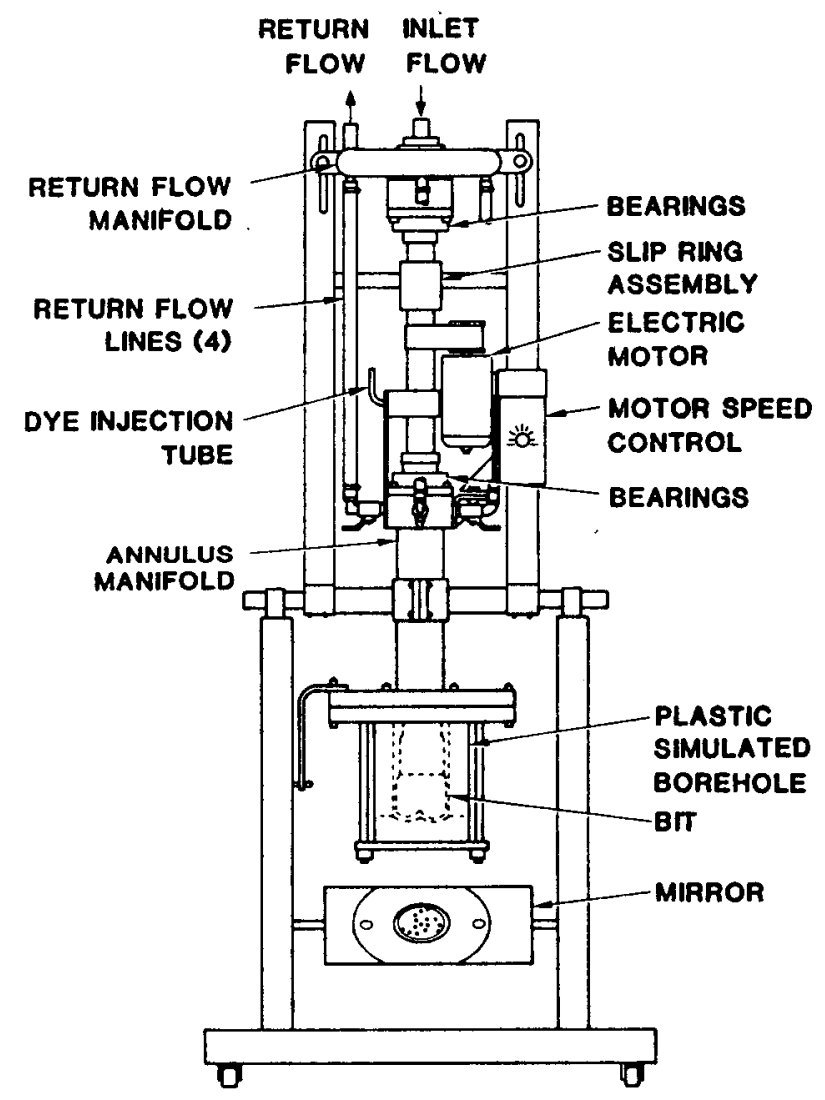

Figure 4. Bit Hydraulics Test Stand 
It was desired in the present study to be able to conveniently assess the effects of electrically connecting the bit to the supporting drill string. This information was desired because it was not known whether the generator sub should be designed utilizing a dielectric material to prevent current bleed-off up the drill string, or if steel could be used throughout. To accomplish this objective, the bit leads were first connected to the test stand leads inside the drill pipe, the connections covered with silicone rubber sealant, and the bit connected to the drill pipe with a rubber sleeve and hose clamps, in lieu of the threaded steel coupling normally used in the test stand. The bit is thus initially insulated from the grounded test stand but can be externally grounded through lead B.

Prior to installing the bit in the test stand, an anode was inserted into the anode fixture. Since the fixture is constructed of steel and is energized along with the anode, it is imperative that the fixture surfaces themselves be insulated to prevent contact with the fluid. This was accomplished by threading the anode into the fixture and sealing the threaded joint with silicone rubber. In this way, only the anode material itself is exposed to the fluid.

\section{Galvanic Voltage Measurements}

Galvanic or "battery" voltages exist whenever two dissimilar metals are immersed in an electrolytic solution. It was the goal of this study to minimize these voltages between various parts of the bit by employing lead wires made of steel. Of course, galvanic voltages cannot be avoided between the bit and the anode, if an anode material other than steel is employed. In fact, the galvanic voltage measured between the bit and the anode has exactly the same magnitude and the opposite polarity of the impressed bit-anode voltage required to suppress the galvanic current responsible for corrosive wear of the bit. The primary purpose of measuring these galvanic voltages was, therefore, to determine the 
magnitude of the required suppression voltage.

Galvanic voltages between the various leads were measured with a digital voltmeter. The results are presented in Section IV.

D. Resistance Measurements

For purposes of analyzing current paths between the anode and various points on the bit, the electrical resistance through the bit and the fluid conductivity were measured. It was not possible to simply use an ohmmeter for these measurements because the operating voltage of a typical ohmmeter is on the same order $(\mathrm{mV})$ as the galvanic voltages developed between various points on the bit. This leads to erroneous resistance values because the ohmmeter logic is not capable of accounting for the superimposed galvanic voltages. In other words, the ohmmeter supplies a given voltage, measures the resulting current, and computes a resistance. The ohmmeter is not "aware" that a galvanic voltage exists and that the actual impressed voltage is the algebraic sum of the galvanic voltage and the voltage supplied by the ohmmeter. If these two voltages are of different polarity, for instance, the measured current can actually be in the opposite direction anticipated by the ohmmeter, causing the ohmmeter to display a negative resistance.

To overcome this problem and obtain realistic resistance values, measured voltages much higher than the galvanic values were impressed between various points, and the resulting currents were measured. From these values effective resistance values were computed. The circuit diagram in Figure 5 shows how this technique was employed. The results are presented in Section IV. 


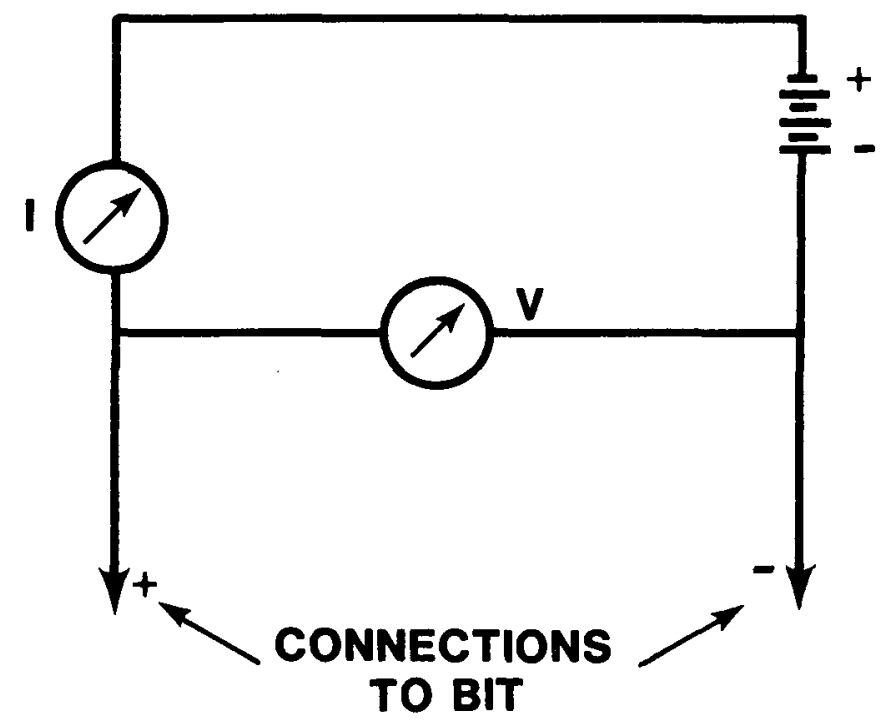

Figure 5. Circuit for Measuring Effective Resistances

\section{E. Voltage Drop Measurements}

One of the questions which prompted this study was whether or not the voltage applied by the generator sub would attenuate in such a small distance from the pin of the bit that no effective potential would be applied to the bit teeth, where the majority of the corrosive wear occurs. This question was resolved by employing the circuit shown in Figure 6. A voltage was impressed between $A$ and $B$, and the voltage drops between $B$ and the contacting leads were measured. The results presented in Section IV indicate that negligible voltage drop exists between $B$ and the contacting points; therefore, the bit teeth can easily be protected from corrosion by applying a voltage to the bit body. 


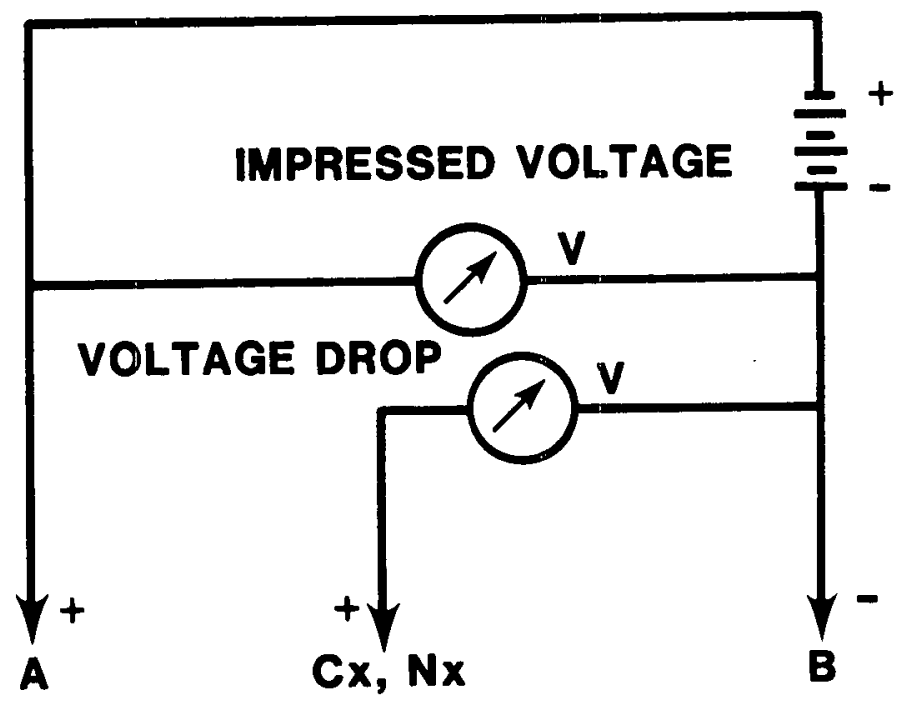

Figure 6. Circuit for Measuring Voltage Drops

F. Tota1 Current Measurements

In order to determine the total current and power required to be delivered by the generator sub, the circuit shown in Figure 7 was employed.

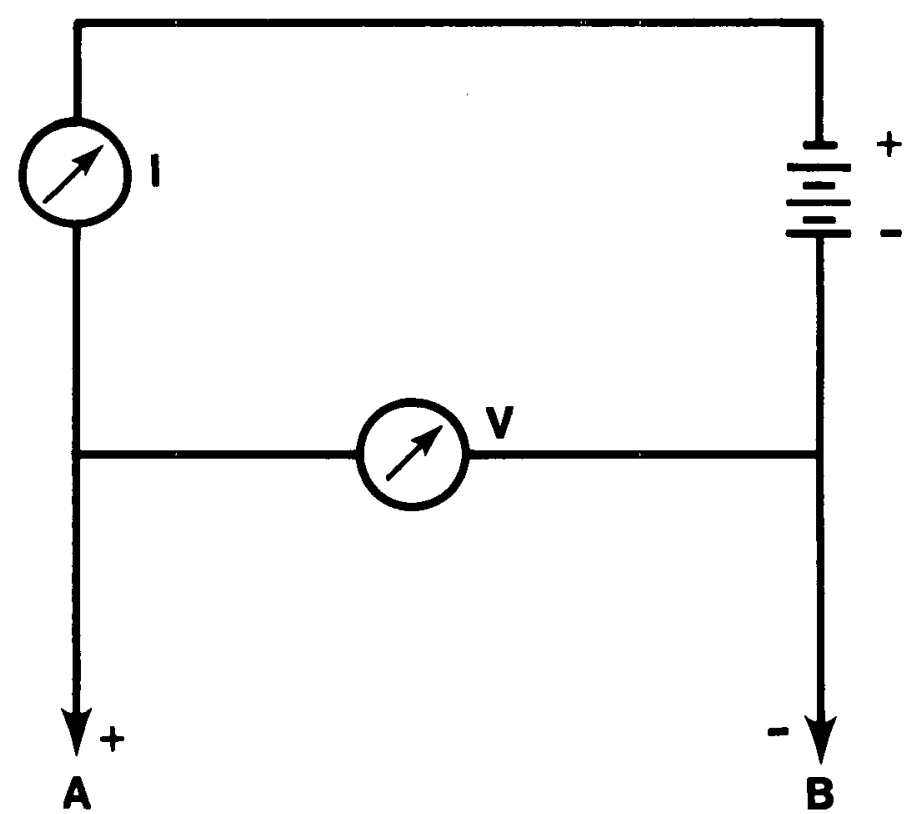

Figure 7. Circuit for Measuring Total Current 
Various voltage levels were applied between $A$ and $B$, and the resulting total currents were measured. The results presented in Section IV indicate very low current and power requirements. This implies that the generator sub would not remove much hydraulic power from the drilling fluid, nor would its design require extensive optimization for achieving high efficiency.

\section{PRESENTATION OF RESULTS}

For the measurements described in the preceding section, three anode materials were employed. The first two anodes were constructed of 1018 steel and 2024 aluminum, respectively. The third anode was constructed of 1018 steel, but the surfaces exposed to the fluid were coated with silver solder, composed of silver, copper, zinc, and cadmium.

All tests were run in the bit hydraulics test stand, at a nominal tap water flow rate through the bit of $30 \mathrm{gal} / \mathrm{min}$. Higher flow rates were found to have no effect on the results; however, lower fluid conductivities were noted when the fluid was stagnant (zero flow). At the nominal flow rate, bit rotation seemed to have no effect on the results. In all cases reported here, the bit was grounded to simulate the electrical connection to a drill stem; however, the results changed only negligibly when the bit was insulated from the test stand. Al1 results are given in Tables 1 through 4.

The anode used in these tests are shown in Figure 8 . The stee1 anode shows the effects of both corrosion and scale formation as iron which goes into solution reacts with water anions, $\mathrm{SO}_{4}{ }^{2}, \mathrm{CO}_{3}{ }^{=}$, and $\mathrm{OH}^{-}$, to form an anodic scale. Consequently, the corrosion which occurs is very irregular. The aluminum anode appears to be mildly pitted, as the oxide film provided protection from corrosion. The silver solder anode is covered with a uniform black precipitate of $\mathrm{CuCl}$. 
Table 1. Galvanic Voltage Measurements

\begin{tabular}{|c|c|c|c|c|}
\hline & & \multicolumn{3}{|c|}{ Ga1vanic Voltage, $\mathrm{mV}$} \\
\hline \multicolumn{2}{|c|}{$\begin{array}{c}\text { Connection } \\
+\end{array}$} & $\begin{array}{l}\text { Steel } \\
\text { Anode }\end{array}$ & $\begin{array}{l}\text { Aluminum } \\
\text { Anode }\end{array}$ & $\begin{array}{c}\text { Silver Solder } \\
\text { Anode }\end{array}$ \\
\hline A & B & -47 & +82 & +310 \\
\hline A & $\mathrm{C} 1$ & -49 & +81 & +307 \\
\hline A & $\mathrm{C} 2$ & -49 & +81 & +305 \\
\hline A & $\mathrm{C} 3$ & -49 & +79 & +305 \\
\hline A & N1 & -50 & +99 & +290 \\
\hline A & $\mathrm{N} 2$ & -119 & +63 & +258 \\
\hline A & N3 & -158 & +35 & +220 \\
\hline A & N4 & -159 & -9 & +211 \\
\hline B & $\mathrm{C} 1$ & 0 & 0 & 0 \\
\hline B & C2 & 0 & 0 & 0 \\
\hline B & $\mathrm{C} 3$ & 0 & 0 & 0 \\
\hline B & N1 & 0 & +19 & -16 \\
\hline B & N2 & -64 & -52 & -50 \\
\hline B & N3 & -109 & -45 & -80 \\
\hline B & N4 & -101 & -86 & -90 \\
\hline N1 & $\mathrm{N} 2$ & -67 & -39 & -38 \\
\hline N1 & N3 & -108 & -64 & -68 \\
\hline N1 & N4 & -105 & -102 & -78 \\
\hline $\mathrm{N} 2$ & N3 & -45 & -24 & -32 \\
\hline N2 & N4 & -35 & -60 & -43 \\
\hline N3 & N4 & +1 & -37 & -11 \\
\hline
\end{tabular}


Table 2. Resistance Measurements

\begin{tabular}{|c|c|c|c|c|}
\hline & \multicolumn{3}{|c|}{ Effective Resistance, $\Omega^{*}$} \\
\cline { 2 - 5 } Connection & $\begin{array}{c}\text { Stee1 } \\
\text { Anode }\end{array}$ & $\begin{array}{c}\text { Aluminum } \\
\text { Anode }\end{array}$ & $\begin{array}{c}\text { Silver Solder } \\
\text { Anode }\end{array}$ \\
\hline+ & - & & & 2300 \\
\hline A & B & 1870 & 1850 & 2300 \\
A & C1 & 1850 & 1770 & 2300 \\
A & C2 & 1870 & 1770 & 2300 \\
A & C3 & 1870 & 1770 & 5130 \\
A & N1 & 4260 & 4650 & 4440 \\
A & N2 & 3330 & 3920 & 4080 \\
A & N3 & 3230 & 3510 & 4260 \\
A & N4 & 3450 & 3640 & 1470 \\
N1 & B & 1120 & 1430 & 2350 \\
N2 & B & 1030 & 1700 & 2350 \\
N3 & B & 1040 & 1340 & 4340 \\
N4 & B & 740 & 2860 & 0.35 \\
C1 & B & 0.35 & 0.35 & 0.35 \\
C2 & B & 0.35 & 0.35 & 0.35 \\
C3 & B & 0.35 & 0.35 & \\
\hline
\end{tabular}

*Effective resistance $=\mathrm{V} / \mathrm{i}-\mathrm{R}_{\mathrm{L}}$

where $\mathrm{V}=$ impressed voltage $=2.0 \mathrm{~V}$ for $\mathrm{A}-\mathrm{B}, \mathrm{A}-\mathrm{C}_{\mathrm{X}}, \mathrm{A}-\mathrm{N}_{\mathrm{X}}, \mathrm{N}_{\mathrm{X}}-\mathrm{B}$

$i=$ measured current

$\mathrm{R}_{\mathrm{L}}=$ lead resistance $=0.35 \Omega$

Measurements taken once steady-state is achieved-- 15 seconds after connection. 
Tab1e 3. Vo1tage Drop Measurements

\begin{tabular}{|c|c|c|c|c|c|c|c|}
\hline \multirow{2}{*}{\multicolumn{2}{|c|}{ Connection }} & \multicolumn{6}{|c|}{ Measured Voltage Drop, $\mathrm{mV}$} \\
\hline & & \multicolumn{2}{|c|}{$\begin{array}{l}\text { Steel } \\
\text { Anode }\end{array}$} & \multicolumn{2}{|c|}{$\begin{array}{l}\text { Aluminum } \\
\text { Anode }\end{array}$} & \multicolumn{2}{|c|}{$\begin{array}{c}\text { Silver Solder } \\
\text { Anode }\end{array}$} \\
\hline+ & - & 2.00 & $10.00 \%$ & 2.00 & $10.00 \%$ & $2.00^{*}$ & $10.00 *$ \\
\hline $\mathrm{Cl}$ & B & 0.2 & 1.7 & 0.2 & 2.1 & 0.2 & 1.4 \\
\hline $\mathrm{C} 2$ & B & 0.2 & 1.7 & 0.2 & 2.1 & 0.2 & 1.4 \\
\hline $\mathrm{C} 3$ & B & 0.2 & 1.7 & 0.2 & 2.1 & 0.2 & 1.4 \\
\hline
\end{tabular}

*Applied $\mathrm{A}^{+}-\mathrm{B}^{-}$voltage 
Table 4. Total Current and Power Measurements

\begin{tabular}{|c|c|c|c|c|c|c|c|}
\hline \multirow[b]{2}{*}{$\mathrm{A}^{+}$} & \multirow[b]{2}{*}{$\begin{array}{l}\text { Applied } \\
-B^{-} \text {voltage } \\
\text { vo1ts }\end{array}$} & \multicolumn{3}{|c|}{$\begin{array}{c}\text { Measured Tota } 1 \\
\text { Current, mA }\end{array}$} & \multicolumn{3}{|c|}{$\begin{array}{l}\text { Tota1 Generator } \\
\text { Sub Power, mw* }\end{array}$} \\
\hline & & $\begin{array}{l}\text { Steel } \\
\text { Anode }\end{array}$ & $\begin{array}{l}\text { Aluminum } \\
\text { Anode }\end{array}$ & $\begin{array}{l}\text { Silver } \\
\text { Solder } \\
\text { Anode }\end{array}$ & $\begin{array}{l}\text { Steel } \\
\text { Anode }\end{array}$ & $\begin{array}{l}\text { Aluminum } \\
\text { Anode }\end{array}$ & $\begin{array}{l}\text { Silver } \\
\text { Solder } \\
\text { Anode }\end{array}$ \\
\hline & 0.50 & .290 & .240 & .037 & .15 & .12 & .019 \\
\hline & 0.60 & .350 & .291 & .076 & .21 & .17 & .046 \\
\hline & 0.70 & .410 & .343 & .125 & .29 & .24 & .088 \\
\hline & 0.80 & .460 & .410 & .178 & .37 & .33 & .14 \\
\hline & 0.90 & .520 & .489 & .232 & .47 & .44 & .21 \\
\hline & 1.0 & .570 & .569 & .282 & .57 & .57 & .28 \\
\hline & 1.1 & .630 & .638 & .338 & .69 & .70 & .37 \\
\hline & 1.2 & .690 & .707 & .393 & .83 & .85 & .47 \\
\hline & 1.3 & .740 & .790 & .451 & .96 & 1.0 & .59 \\
\hline & 1.4 & .800 & .890 & .508 & 1.1 & 1.2 & .71 \\
\hline & 1.5 & .860 & .965 & .565 & 1.3 & 1.4 & .85 \\
\hline & 2.0 & 1.15 & 1.39 & .860 & 2.3 & 2.8 & 1.7 \\
\hline & 3.0 & 1.72 & 2.15 & 1.45 & 5.2 & 6.5 & 4.4 \\
\hline & 4.0 & 2.29 & 2.95 & 2.04 & 9.2 & 11.0 & 8.2 \\
\hline & 5.0 & 2.83 & 3.77 & 2.64 & 14.0 & 19.0 & 1.3 \\
\hline & 10.0 & 5.96 & 7.80 & 5.68 & 60.0 & 78.0 & 57.0 \\
\hline & 20.0 & 13.9 & 16.2 & 11.8 & 280 & 320 & 240 \\
\hline & 2.0 & 1.40 & 1.52 & .870 & 2.8 & 3.0 & 1.7 \\
\hline
\end{tabular}

*Total Generator Sub Power $=\mathrm{V} * \mathrm{i}$

where $V=$ Applied $A^{+}-B^{-}$voltage, volts

$i=$ Measured total current, $\mathrm{mA}$ 


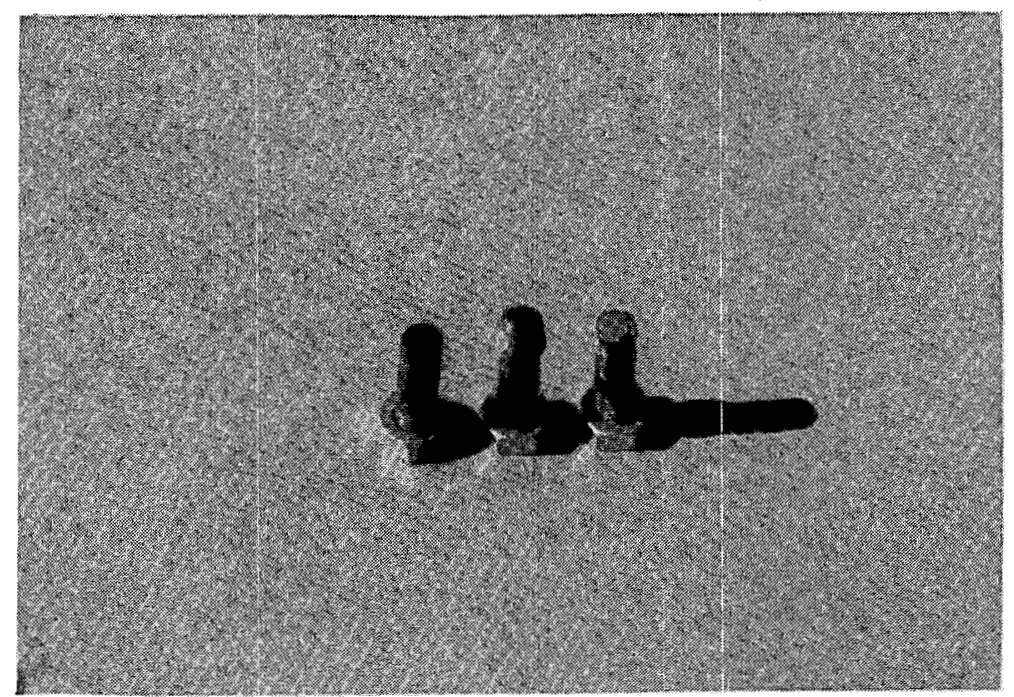

Figure 8. Anodes Employed in Study: (left to right)

Stee1, Silver Solder, Aluminum

\section{ANALYSIS}

A. Description of Electrical Path

The flow of electrons in these experiments has been directed toward the bit body (or cathode) where the reduction of $\mathrm{O}_{2}$ occurs by reaction (2) (see page 7). At the metal surface, $\mathrm{OH}^{-}$ions then are produced and begin to migrate away from the bit body toward the anode. At the anode, either positive ions must be produced or negative ions must be consumed in order to maintain electrical neutrality in the fluid. If the anode reaction is a sacrificial one (in which anode material enters solution) then reaction (1) is appropriate. Other anode reactions may occur, as will be discussed later. In any event, the primary resistance to current flow lies in the fluid, where ionic migration occurs. Since this ionic migration is influenced by ionic strength (solution concentration), ionic mobilities, solution temperature, and fluid flow, it is to be expected that different effective resistances will result from altering the fluid flow field, the solution concentration, or the anode and cathode materials or reactions. 
The anode and cathode materials have an additional impact on the measurement of resistances in the fluid since these materials also form a battery, and as such, impose a potential of their own as may be seen from Table 1. These potentials influence the effective resistance measurements given in Table 2. Since resistance is calculated by dividing voltage by current, the case where a non-zero voltage exists at zero current leads to the false conclusion that the resistance is infinite. At larger currents the resistance diminishes eventually to an asymptotic value. This asymptotic value is also obtained by dividing the change in voltage by the change in current. Hence, the effective resistance of the silver solder anode, for instance, will become

$$
R=\frac{V-V_{0}}{i-i_{0}}
$$

If $V_{0}$ is taken to be the galvanic voltage given in Table 1 and $i_{0}$ is zero at this condition, then for the connection A-B in Table 2, with $i$ inferred from Table 2 and $V$ set at $2.0 \mathrm{~V}$,

$$
R=\frac{2.0 \mathrm{~V}-0.3 \mathrm{~V}}{0.00087 \mathrm{amp}}=1950 \Omega
$$

This resistance is now comparable with those for the steel anode, $1870 \Omega$, and the aluminum anode, $1850 \Omega$, where the galvanic potentials are essentially zero.

The fact that the effective resistance for all three anodes is comparable indicates that most of the current flow in the water is carried by dissolved minerals in the water rather than the ions given off by either the anode or the cathode. When, for instance, $\mathrm{Fe}^{++}$is given off at the anode, dissolved $\mathrm{Ca}^{++}$in the water is displaced from the vicinity of the anode to maintain electrical neutrality in the fluid. $\mathrm{Ca}^{++}$is present in the tap water used in these experiments at a concen- 
tration of $41 \mathrm{mg} / 1$, while the maximum concentration of $\mathrm{Fe}^{++}$is expected to be $1 \mathrm{mg} / 1$. The $\mathrm{Ca}^{++}$thus displaced from the anode vicinity will displace another $\mathrm{Ca}^{++}$ion in an adjoining vicinity so that electrical neutrality will be maintained there. This process will be repeated all along the path between the anode and the cathode until an extra $\mathrm{Ca}^{++}$ ion shows up at the cathode. The negative ion produced or the positive ion consumed there will close the current loop in the fluid. Whether or not $\mathrm{Ca}^{++}$or $\mathrm{Cl}^{-}$or some other ion carries most of the charge through the fluid depends on their relative concentrations and their relative ionic mobility in the fluid. In any event, the consistency of the resistance measurements for three different metal anodes indicates that the ion concentration is high enough (even with tap water) to assure that the ions generated at anode and cathode do not carry significant current.

A further comparison of resistances in Table 2 indicates that the resistances between $A$ and the nonconducting probes N1, N2, N3 and N4 are larger than the A - B resistance. This is due to the increased path length in the fluid. It should also be noticed that the resistance between $\mathrm{B}$ and $\mathrm{C} 1, \mathrm{C} 2$, and $\mathrm{C} 3$ are insignificant compared to these fluid resistances. This indicates that very little voltage attenuation is to be expected through the metal bit body and bearings between the threaded connection and the teeth of the roller cones. This important conclusion is further verified in Table 3 , where it is seen that for a $2.0 \mathrm{~V}$ potential impressed between $A$ (the anode) and the bit body, B, the potential at the roller cone teeth is only $0.2 \mathrm{mv}$ less than B. Stating this another way, $99.99 \%$ of the voltage impressed between $A$ and $B$ is realized at the bit teeth.

From the theory of conductance of electrolytes ${ }^{4}$ it is known that the conductance of an electrolyte is linearly proportional to the concentration of the electrolyte. For our use where the conductance of 
the liquid path is 5000 times lower than that through the metal, then the concentration of the fluid may be increased by a factor of 1000 before approaching the metal conductance. This corresponds to a fluid concentration of $0.6 \mathrm{M} \mathrm{NaCl}$ or $13 \mathrm{lb} / \mathrm{bbl} \mathrm{NaCl}$. At these high concentrations of $\mathrm{NaCl}$ or some other salt, the resistance of the fluid path would start to become comparable to that through the bit body, and at this condition more power would have to be applied to the bit to maintain cathodic protection.

\section{B. Ha1f-Cell Reactions}

\section{Cathode Reaction}

It is the intent of the proposed downhole device to change the electrical potential of the bit body so that it becomes cathodic with respect to some anode. The most probable cathode reaction is

$$
\mathrm{O}_{2}+2 \mathrm{H}_{2} \mathrm{O}+4 \mathrm{e}^{-}=4 \mathrm{OH}^{-}
$$

and the potential for this reaction is

$$
\mathrm{E}=0.401-.000198 \mathrm{~T} \log \frac{\left[\mathrm{OH}^{-}\right]}{\mathrm{P}_{\mathrm{O}_{2}^{\frac{1}{4}}}}
$$

where $\mathrm{E}$ is the potential in volts, $\mathrm{T}$ is the temperature in ${ }^{\circ} \mathrm{K},\left[\mathrm{OH}^{-}\right]$is the concentration of hydroxide ion and $\mathrm{P}_{\mathrm{O}_{2}}$ is the partial pressure, in atmospheres, of oxygen in equilibrium with the solution. For typical downhole conditions, the solution concentration is fixed by aerated conditions at the surface so that $\mathrm{P}_{\mathrm{O}_{2}}$ is $0.21 \mathrm{~atm}$. At $60^{\circ} \mathrm{C}$, $\mathrm{E}$ is given by

$$
E=0.401-.0660(\mathrm{pH}-13.83)
$$

or at a $\mathrm{pH}$ of $7.0, \mathrm{E}$ is $0.852 \mathrm{~V}$. 
One other cathode reaction, which is undesirable but may occur if the solution oxygen level becomes too depleted, is

$$
\mathrm{H}^{+}+\mathrm{e}^{-}=1 / 2 \mathrm{H}_{2}(\mathrm{~g})
$$

The potential for this reaction is about 0.8 volts less than reaction (7), and it is definitely not thermodynamically favored. However, if hydrogen were formed, then embrittlement problems would have to be considered. The major reason why reaction (8) may actually occur would be that the amount of dissolved oxygen could become so low that the potential of reaction (5) falls below that of (8). This could only happen locally in a stagnant situation if an excessive 0.8 volt overpotential were applied and the local solution concentration of oxygen fell below $10^{-48} \mathrm{ppb}$. One advantage of the generator sub considered in the present study is that no voltage would be produced when fluid flow is stopped and stagnant conditions exist. Additionally, voltage control could be specified so that this excessive over-voltage would not occur.

\section{Anode Reactions}

Iron

There are several possible anode reactions which may be considered, depending on the selection of the anodic material. The cheapest choice of anode material is iron. In this case, the anode reaction is

$$
\mathrm{Fe} \rightarrow \mathrm{Fe}^{++}+2 \mathrm{e}^{-}
$$

for which the potential for reaction is

$$
\mathrm{E}=0.44-.000198 \mathrm{~T} \log \left[\mathrm{Fe}^{++}\right]
$$

Since iron has a limited solubility in water and at $60^{\circ} \mathrm{C}$ the concentration of iron $\left(\mathrm{Fe}^{++}\right.$) is $2.1 \times 10^{-6} \mathrm{~mol} / 1$, (10) has a limiting value 
of $0.59 \mathrm{~V}$. Since the iron in the anode has the same tendency to react as does the bit body, only a small potential (less than $0.8 \mathrm{~V}$ ) needs to be applied to the anode to protect the bit. At this voltage, the current used will be less than $0.46 \mathrm{~mA}$ as seen by Table 4 .

Aluminum

If aluminum is chosen as the anode material, the anode reaction is

$$
\mathrm{A} 1 \rightarrow \mathrm{A1}+3+3 \mathrm{e}^{-}
$$

and the potential for this reaction is

$$
\mathrm{E}=1.66-.000198 \mathrm{~T} \log \left[\mathrm{A} 1^{+++}\right]
$$

Since aluminum forms a protective oxide film, the potential given by (12) may not be realized in neutral solutions. However, aluminum oxide is amphoteric and dissolves in either acidic or basic media. If the protective film remains intact, then reaction (11) will not occur and the reverse of reaction (5) must occur. In this case at least $1.7 \mathrm{~V}$ must be applied to make sure that the bit body is protected. If the protective oxide film becomes destroyed, then reaction (11) will occur. In this case the reaction will become spontaneous with a potential of $2.5 \mathrm{~V}$. Because of the possible large variation in potential with an aluminum anode, two extremes of operation appear likely. In the first case either no protection may be afforded if the protective film remains intact and insufficient voltage is provided to reverse reaction (5). In the second case hydrogen may be evolved at the bit if voltage is provided to reverse reaction (5) and the protective film breaks down. Because of these possible adverse modes of operation it is felt that aluminum would be a poor choice of anode material.

An examination of the measured total current data in Table 4 highlights this problem. At low applied voltages the current levels observed 
for the aluminum anode are less than those observed for the steel anode. At higher voltages, the protective oxide film appears to be breaking down and increased currents are observed (relative to steel) as aluminum becomes anodically active.

\section{Silver Solder Anode}

The silver solder anode is composed of silver, copper, zinc, and cadmium. This material was examined out of the belief that it may offer stable operating characteristics while being amenable to field reconditioning. The primary reaction which occurs when this material is chosen as an anode is that of copper with chloride ion

$$
\mathrm{Cu}+\mathrm{Cl}^{-} \rightarrow \mathrm{CuC} 1+\mathrm{e}^{-}
$$

and

$$
\mathrm{E}=0.137-.000198 \mathrm{~T} \log \left[\mathrm{Cl}^{-}\right]
$$

For the tap water used in our experiments the chloride concentration was $23 \mathrm{mg} / 1$ so that in our experiments the anode potential was $-0.32 \mathrm{~V}$. Hence, cathodic protection of the drill bit would be afforded through the application of $0.26 \mathrm{~V}$.

Table 4 shows that the cathodic current measured with the silver solder anode is comparable to that with the steel anode displaced by $0.5 \mathrm{~V}$, i.e., the current required using the silver solder anode at $1.3 \mathrm{~V}$ is roughly equivalent to the current required by the steel anode at $0.8 \mathrm{~V}$. It is to be expected that this displacement would have corresponded to $0.26 \mathrm{~V}$, but considering that silver solder is not a pure copper anode, this agreement is satisfactory.

Non-Sacrificial Anodes

A11 of the anodes considered to this point will be consumed in protecting the drill bit. If we desire to force the reverse of reaction 
(5) to become the anodic reaction, then oxygen will be generated at the anode and an electrode potential of approximately $0.85 \mathrm{~V}$ will be required. Since the reaction with the most positive electrode potential will occur at any electrode, a material with a more negative electrode potential than $-0.85 \mathrm{~V}$ will be required to form a non-sacrificial anode. Only graphite and the noble metals, gold and platinum, meet this criterion. Since gold and platinum may have a rate of disappearance not related to any corrosion problem and have prohibitive cost, graphite is the more acceptable anodic material.

Another advantage of a graphite anode would be that scaling of the anode would be minimized. Since $\mathrm{OH}^{-}$ions are consumed at the anode, positive ions will also have to migrate away from the anode to preserve electrical neutrality. In this way both positive and negative ions are depleted and solution concentration is thus locally reduced. Under these conditions scaling would not be a problem.

\section{Power and Voltage Requirements}

As has been discussed earlier, power requirements are anode dependent. Since the voltages required to maintain cathodic protection are smallest with a steel anode, the power requirements are also smallest with stee1. At 0.8 volts between the anode and the bit body, the current required is $0.46 \mathrm{ma}$, or the power required is $0.37 \mathrm{mw}$.

Because of the instability of the aluminum oxide film on the aluminum anode, the power requirement for the aluminum anode is variable. If the film remains intact, then protection of the bit is obtained when the voltage is less than or equal to $0.8 \mathrm{~V}$, and the maximum current observed under these circumstances is $0.41 \mathrm{ma}$. Hence, the power required will be $0.33 \mathrm{mw}$. If the aluminum oxide film does break down, then the reaction would become spontaneous with a voltage of $2.5 \mathrm{~V}$, and the anticipated current would be approximately $1.4 \mathrm{ma}$. There would be no power required in this case as aluminum would be spontaneously reacting to 
protect the steel bit body.

The silver solder anode is characterized by essentially a coppercopper chloride reaction and the same level of protection using this anode requires a potential of 1.3 volts and a current of $0.451 \mathrm{ma}$. The power required would be $0.59 \mathrm{mw}$.

Lastly, if we consider a non-sacrificial anode then reaction (5) would occur at the cathode or bit body and the reverse of reaction (5) would occur at the anode. The total potential required to make this reaction occur would be $1.7 \mathrm{~V}$. If the overpotential is limited to $0.8 \mathrm{~V}$, as before, then $2.5 \mathrm{~V}$ would be required and the anticipated current would be $0.45 \mathrm{ma}$. Hence, the power requirement would be $1.1 \mathrm{mw}$.

The power required for any of these cases is so small that the design of the system for any of the anodes would be similar. One milliwatt of power or less is a very small fraction of the $400 \mathrm{hp}(300 \mathrm{kw})$ typically available in the fluid stream. In addition, the wear protection and corrosion protection would be the same with the steel, silver solder, or with the non-sacrificial (graphite) anodes.

\section{$\underline{\text { DISCUSSION }}$}

A. Suppression of Corrosion and Wear

The use of galvanic currents to suppress corrosion ${ }^{5}$ and wear ${ }^{1}$ are we11 documented, and it appears from these references that both effects require a comparable current level. The results shown in Table 3 indicate that the voltage attenuation is very small for fluids of the ionic strength of tap water. The addition of drilling mud to the water will not significantly affect these results because mud particles migrate in an electric field as an electrophoretic current. Since the mud particles are much larger than the dissolved ions, their mobility is expected to be much smaller than the ions and hence, only a small percentage of the current is expected to be carried by the mud. 
The extension of the current work to estimate how much of the dri11 string might be protected by a downhole generator is an important subject to be considered. The results of Table 4 indicate that $0.46 \mathrm{ma}$ will protect the drill bit used in these tests, whose surface area is approximately $150 \mathrm{in}^{2}$. This may be compared to $1 \mathrm{ft}$ of $4 \mathrm{in.,} 15.70$ $1 \mathrm{~b} / \mathrm{ft}$ drill pipe whose surface area is $250 \mathrm{in}^{2}$. Since the drill bit experiences a voltage drop at the cones of $0.2 \mathrm{mV}$ and we can tolerate a voltage drop of $0.8 \mathrm{~V}$, it is inferred that 400 times as much surface area may be protected. In other terms, approximately $250 \mathrm{ft}$ of dri11 pipe could be protected, and the current level necessary to protect the drill pipe would be 400 times greater than that measured in the laboratory, or a maximum of $0.18 \mathrm{amp}$ would be required. The power level would be $0.15 \mathrm{w}$.

\section{B. Selection of Anode Type}

The selection of the anode type is seen to be a choice between either a renewable, expendable anode or a non-sacrificial anode. From a consideration for expense and consistency of operation, it is felt that iron or steel represents the anode of choice if an expendable anode is desired. It should be recognized that an iron or steel anode will undergo significant corrosion and perhaps fluid erosion as well as the more predictable metal loss as a result of the electrolytic current. Hence, the anode will have to be several times larger than that predicted in Section $\mathrm{V}-\mathrm{C}$.

If a non-sacrificial anode is used, graphite is the obvious material to choose. Although this material was not tested in the laboratory, it is felt that graphite would be a better choice than iron because of its low cost and permanence. Additionally, no scaling problems are to be expected with graphite, and hence, its performance is expected to be very consistent. 


\section{Anode Size}

The anodic size depends upon the type of anode chosen and the replacement frequency. If iron or steel is chosen as the anodic material and protection of the bit is all that is required then the current leve1 is $0.46 \mathrm{~mA}$. In one day, then

$$
(0.00046 \mathrm{amp})(1 \mathrm{day})\left(\frac{24 \mathrm{hr}}{\mathrm{day}}\right)\left(\frac{3600 \mathrm{sec}}{\mathrm{hr}}\right)\left(\frac{1 \mathrm{C}}{\mathrm{amp}-\mathrm{sec}}\right)=39.7 \mathrm{C}
$$

are required. Since $96,500 \mathrm{C}$ will consume one gm equivalent or 27.925 gm Fe, then in one day $39.7 \mathrm{C} \frac{27.925 \mathrm{~cm}}{96500 \mathrm{C}}=0.0115 \mathrm{gm} \mathrm{Fe}$ wil1 be consumed. In two weeks then, $0.16 \mathrm{gm} \mathrm{Fe}$ will be used. If we desire to protect $250 \mathrm{ft}$ of drill pipe as well then $64 \mathrm{gm}$ of $\mathrm{Fe}$ will be consumed in two weeks.

It is pointed out that $64 \mathrm{gm}$ of $\mathrm{Fe}$ lost through this corrosion mechanism is far less than the total metal loss from $250 \mathrm{ft}$ of drill string. Once again, it is recalled that the mechanisms of metal loss are a combination of corrosion, erosion, and abrasion. If the corrosion mechanism is stopped, then al1 of the other mechanisms are significantly reduced. Additionally, the corrosion that does occur is localized to the sacrificial steel anode.

If a graphite anode is used, then it will not be consumed during the course of providing cathodic protection. However, it will have to be sized large enough so that the relatively low electrical conductivity of graphite does not cause significant parasitic power losses. This may be achieved by requiring the resistance of the graphite anode to be less than $1 \%$ of the effective fluid resistance. These criterion are met by a graphite anode which is $6 \mathrm{~cm}$ in diameter and $0.5 \mathrm{~cm}$ thick.

D. Effect of Sa1t

If the salt content of the drilling fluid increases, then it is expected that increased currents and power will be required. At the 
same time it is expected that fluid concentrations less than $0.6 \mathrm{~N} \mathrm{NaCl}$ should present no operational problems. As was discussed in IV-A the electrical conductance is linearly related to the salt concentration, expressed as a molality, $\frac{\text { moles salt }}{1000 \mathrm{gm} \text { solvent }}$. Thus, if voltage levels are prescribed, then increasing the salt concentration linearly increases both the current and the power required.

\section{E. Economics}

The approximate economic advantage of using a downhole current source to reduce bit wear rates can be ascertained with data obtained from a well-cost sensitivity study performed by Lin and Carson. 6 According to this data, the total well cost savings resulting from a doubling and quadrupling of bit life are those given in Table 5 . This data includes bit replacement costs and the costs of attendant tripping operations.

These results suggest that between $\$ 65 \mathrm{~K}(9 \%)$ and $\$ 237 \mathrm{~K}(21 \%)$ per well can be saved as a result of increased bit life, depending on the well field and the actual increase in bit 1 ife achieved. These figures do not include any savings which could be realized by preventing or reducing drill pipe corrosion; however, such savings are expected to be significant in certain wells since the huge costs of corrosion chemicals normally employed to control corrosion would be eliminated. These figures also do not take into account the extra costs associated with the downhole generator sub or battery pack. Estimates of these costs would have to await the results of any preliminary engineering design of the system to be developed and employed; however, these costs are not expected to be a significant portion of the potential savings. 
Table 5. Potential Well Cost Savings

\begin{tabular}{|c|c|c|c|}
\hline Well Field & $\begin{array}{c}\text { Typica1 } \\
\text { We11 Cost } \\
\end{array}$ & $\begin{array}{l}\text { Potential Savings } \\
\text { with Doubling of } \\
\text { Bit Life, } \%\end{array}$ & $\begin{array}{l}\text { Potential Savings } \\
\text { with Quadrupling } \\
\text { of Bit Life, } \frac{\circ}{0}\end{array}$ \\
\hline The Geysers & $\$ 1.14 \times 10^{6}$ & 12 & 19 \\
\hline East Mesa & $\$ .723 \times 10^{6}$ & 9 & 13 \\
\hline Baca & $\$ 1.08 \times 10^{6}$ & 10 & 15 \\
\hline $\begin{array}{l}\text { Roosevelt } \\
\text { Hot Springs }\end{array}$ & $\$ 1.13 \times 10^{6}$ & 13 & 21 \\
\hline
\end{tabular}

\section{SUMMARY AND CONCLUSIONS}

1. The use of a downhole generator sub or battery pack to reduce drill bit wear through the reduction of corrosion appears to be both technically feasible and economically attractive.

2. Power levels required to protect a 4-1/2 inch roller cone dri11 bit are on the order of $1 \mathrm{mw}$.

3. Power levels required to protect up to 250 feet of 4 inch dril1 pipe are on the order of $150 \mathrm{mw}$.

4. Voltage attenuation levels are very small for the drill bit and are seen to be dependent on applied voltage levels.

5. Salt concentration linearly affects the fluid conductance and hence the power levels required to provide galvanic protection.

6. Several anode materials may be used; however, either iron or graphite is selected as the best candidate material. If iron is chosen, replacement of the anode would be required. If graphite is chosen, the anode should be configured so that it has a surface diameter of approximately $6 \mathrm{~cm}$ or greater and a thickness of $0.5 \mathrm{~cm}$ or less in order to prevent excessive parasitic power loss in the anode itself. 


\section{REFERENCES}

I. Hoenig, S. A., R. Zanoni, K. M. Khan, "Application of Electrochemical Technology to the Improvement of Rock Drilling Systems," Submitted to J. Pet. Tech., July 1981.

2. Caskey, B. C., K. S. Copass, "Drill Pipe Corrosion Control Using an Inert Drilling Fluid," presented at International Conf. on Geothermal Drilling and Technology, Albuquerque, NM, 21-23 Jan. 1981 .

3. Glowka, D. A., "Optimization of Bit Hydraulic Configurations," SPE Paper No. 10240, presented at the 56 th Annual Fall Technical Conference and Exhibition of the Society of Petroleum Engineers of AIME, San Antonio, TX, Oct. 1981.

4. Glasstone, $S$ and $D$. Lewis, Elements of Physical Chemistry, D. Van Nostrand Co. Inc., princeton, NJ, 1960.

5. Smalley, R. and J. Horkondee, "Application of Solar Energy to Producing Operations of Oil and Gas Fields," J. Pet. Tech., 151, Feb. 1979.

6. Lin, Y. T. and Carson, C. C., personal communication, March 1982 .

7. Caskey, B. C., Sandia National Laboratories, Albuquerque, NM, personal communication, March 11, 1982 . 
DISTRIBUTION :

TID-4500-R66-UC-66c (507)

Tom Anderson

Venture Innovations

P.0. Box 35845

Houston, Texas 77035

Ed Bingman

Shel1 Oil Company

Two Shell Plaza

P.O. Box 2099

Houston, Texas 77001

Larry Diamond

Dyna-Dri11

P.O. Box C- 19576

Irvine, California 92713

Tom Turner

Phillips Petroleum Company

Geothermal Operations

655 East 4500 South

Salt Lake City, Utah 84107

Jim Kingsolver

Geothermal Operations

Smith Too1

P.0. Box C-1951I

Irvine, California 92713

John C. Rowley

Los Alamos National Labs

Mail Stop 570

Los Alamos, New Mexico 87545

Ed Martin

Superior Oil

Eastern Division

P.O. Box 51108 OCS

Lafayette, Louisiana 70505

B. J. Livesay

129 Liverpool

Cardiff, California 92008

Dr. Melvin Friedman

Professor of Geology

Center for Tectonophysics

and Dept. of Geology

Texas A\&M University

College Station, Texas 77843
Gene Polk

NL Baroid

6400 Uptown B1vd. N.E., 365W

Albuquerque, New Mexico 87110

James W. Langford

Security Division

Dresser Industries, Inc.

P.0. Box 24647

Da1las, Texas 75224

John E. Fontenot

NL Petroleum Services

P.0. Box 60087

Houston, Texas 77205

De1 E. Pyle

Union Geothermal Division

Union Oil Co. of California

Union Oil Center

Los Angeles, California 90017

William D. Rumbaugh

Research \& Development

otis

P.0. Box 34380

Dallas, Texas 75234

Dwight Smith

Halliburton

Drawer 1431

Duncan, Oklahoma 73533

Tom Warren

Amoco Production Company

Research Center

P.O. Box 591

Tu1sa, Ok1ahoma 74102

H. E. Ma11ory

P.O. Box 54696

Tulsa, Oklahoma 74155

Stuart A. Hoenig

Dept. of Electrical Engineering

University of Arizona

Tucson, Arizona 85721 
DISTRIBUTION : cont.

U. S. Department of Energy

(4) Geotherma1 Hydropower

Technologies Division

Forrestal B1dg., CE 324

1000 Independence Ave. S.W.

Washington, D.C. 20585

Attn: J. Bresee

D. C1ements

R. Toms

D. A11en

W. P. Grace, DOE/ALO

Nuclear \& Geosciences Division

3141 L. J. Erickson

3151 W. L. Garner

9000 G. A. Fowler

9700 E. H. Beckner

9730 W. D. Weart

9740 R. K. Traeger

9741 J. R. Kelsey

9741 D. A. Glowka

9741 J. T. Finger

9746 B. Granoff

9747 P. J. Hommert

9750 V. L. Dugan

9755 T. E. Hinkebein (10)

9760 R. W. Lynch

$\begin{array}{ll}9760 & \text { R. W. Lynch } \\ 8214 & \text { M. A. Pound }\end{array}$ 